\title{
THE CORPORATION
}

Rethinking the Iconic Form of

Business Organization

Ediłed by Renate E. Meyer,

Stephan Leixnering and Jeroen Veldman

RESEARCH IN THE SOCIOLOGY OF ORGANIZATIONS

VOLUME 78

Sponsored by the

ASA section on Organizations,

Occupations and Work 
THE CORPORATION 


\section{RESEARCH IN THE SOCIOLOGY OF ORGANIZATIONS}

\section{Series Editor: Michael Lounsbury}

\section{Recent Volumes:}

Volume 53: structure, content and meaning of organizational networks: extending network thinking

Volume 54A: Multimodality, Meaning, and Institutions

Volume 54B: Multimodality, Meaning, and Institutions

Volume 55: Social Movements, Stakeholders and Non-Market Strategy

Volume 56: Social Movements, Stakeholders and Non-Market Strategy

Volume 57: Toward Permeable Boundaries of Organizations?

Volume 58: Agents, Actors, Actorhood: Institutional Perspectives on the Nature of Agency, Action, and Authority

Volume 59: The Production of Managerial Knowledge and Organizational Theory: New Approaches to Writing, Producing and Consuming Theory

Volume 60: Race, Organizations, and the Organizing Process

Volume 61: Routine Dynamics in Action

Volume 62: Thinking Infrastructures

Volume 63: The Contested Moralities of Markets

Volume 64: Managing Inter-organizational Collaborations: Process Views

Volume 65A: Microfoundations of Institutions

Volume 65B: Microfoundations of Institutions

Volume 66 Theorizing the Sharing Economy: Variety and Trajectories of New Forms of Organizing

Volume 67: Tensions and paradoxes in temporary organizing

Volume 68: Macrofoundations: Exploring the Institutionally Situated Nature of Activity

Volume 69: Organizational Hybridity: Perspectives, Processes, Promises

Volume 70: On Practice and Institution: Theorizing the Interface

Volume 71: On Practice and Institution: New Empirical Directions

Volume 72: Organizational Imaginaries: Tempering Capitalism and tending to communities through cooperatives and collectivist democracy

Volume 73A: Interdisciplinary Dialogues on Organizational Paradox: Learning from Belief and Science

Volume 73B: Interdisciplinary Dialogues on Organizational Paradox: Investigating Social Structures and Human Expression

Volume 74: Worlds of Rankings

Volume 75: Organizing Creativity in the Innovation Journey

Volume 76: Carnegie goes to California: Advancing and Celebrating the Work of James G. March

Volume 77: The Generation, Recognition and Legitimation of Novelty 


\title{
RESEARCH IN THE SOCIOLOGY OF ORGANIZATIONS ADVISORY BOARD
}

\author{
Series Editor \\ Michael Lounsbury \\ Professor of Strategic Management \& Organization \\ Canada Research Chair in Entrepreneurship \& Innovation \\ University of Alberta School of Business
}

\section{RSO Advisory Board}

Howard E. Aldrich, University of North Carolina, USA

Shaz Ansari, Cambridge University, UK

Silvia Dorado Banacloche, University of Massachusetts Boston, USA

Christine Beckman, University of Southern California, USA

Marya Besharov, Oxford University, UK

Eva Boxenbaum, Copenhagen Business School, Denmark

Ed Carberry, University of Massachusetts Boston, USA

Lisa Cohen, McGill University, Canada

Jeannette Colyvas, Northwestern University, USA

Erica Coslor, University of Melbourne, Australia

Gerald F. Davis, University of Michigan, USA

Rich Dejordy, California State University, USA

Rodolphe Durand, HEC Paris, France

Fabrizio Ferraro, IESE Business School, Spain

Peer Fiss, University of Southern California, USA

Mary Ann Glynn, Boston College, USA

Nina Granqvist, Aalto University School of Business, Finland

Royston Greenwood, University of Alberta, Canada

Stine Grodal, Northeastern University, USA

Markus A. Hoellerer, UNSW Sydney, Australia

Ruthanne Huising, emlyon business school, France

Candace Jones, University of Edinburgh, UK

Sarah Kaplan, University of Toronto, Canada

Brayden G. King, Northwestern University, USA

Matthew S. Kraatz, University of Illinois at Urbana-Champaign, USA

Tom Lawrence, Oxford University, UK

Xiaowei Rose Luo, Insead, France

Johanna Mair, Hertie School, Germany

Christopher Marquis, Cornell University, USA

Renate E. Meyer, WU Vienna University of Economics and Business, Austria

William Ocasio, University of Illinois at Urbana-Champaign, USA

Nelson Phillips, Imperial College London, UK

Prateek Raj, Indian Institute of Management Bangalore, India 
Marc Schneiberg, Reed College, USA

Marc-David Seidel, University of British Columbia, Canada

Paul Spee, University of Queensland, Australia

Paul Tracey, Cambridge University, UK

Kerstin Sahlin, Uppsala University, Sweden

Sarah Soule, Stanford University, USA

Eero Vaara, University of Oxford, UK

Marc Ventresca, University of Oxford, UK

Maxim Voronov, York University, canada

Filippo Carlo Wezel USI Lugano, Switzerland

Melissa Wooten, Rutgers University, USA

April Wright, University of Queensland, Australia

Meng Zhao, Nanyang Business School \& Renmin University, China

Enying Zheng, Peking University, China

Tammar B. Zilber, Hebrew University of Jerusalem, Israel 
RESEARCH IN THE SOCIOLOGY OF

ORGANIZATIONS VOLUME 78

\section{THE CORPORATION: RETHINKING THE ICONIC FORM OF BUSINESS ORGANIZATION}

\section{EDITED BY \\ RENATE E. MEYER}

WU Vienna University of Economics and Business, Austria

Copenhagen Business School, Denmark

\section{STEPHAN LEIXNERING}

WU Vienna University of Economics and Business, Austria

and

\section{JEROEN VELDMAN}

Nyenrode Business University, Netherlands

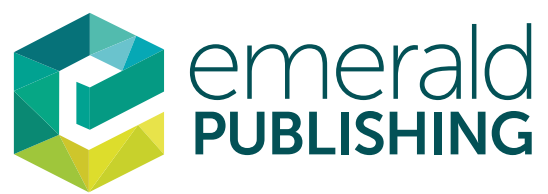

United Kingdom - North America - Japan

India - Malaysia - China 
Emerald Publishing Limited

Howard House, Wagon Lane, Bingley BD16 1WA, UK

First edition 2022

Copyright (C 2022 Emerald Publishing Limited

Reprints and permissions service

Contact: permissions@emeraldinsight.com

No part of this book may be reproduced, stored in a retrieval system, transmitted in any form or by any means electronic, mechanical, photocopying, recording or otherwise without either the prior written permission of the publisher or a licence permitting restricted copying issued in the UK by The Copyright Licensing Agency and in the USA by The Copyright Clearance Center. Any opinions expressed in the chapters are those of the authors. Whilst Emerald makes every effort to ensure the quality and accuracy of its content, Emerald makes no representation implied or otherwise, as to the chapters' suitability and application and disclaims any warranties, express or implied, to their use.

\section{British Library Cataloguing in Publication Data}

A catalogue record for this book is available from the British Library

ISBN: 978-1-80043-377-9 (Print)

ISBN: 978-1-80043-376-2 (Online)

ISBN: 978-1-80043-378-6 (Epub)

ISSN: 0733-558X (Series) 


\section{CONTENTS}

About the Contributors ix

Foreword: Research in the Sociology of Organizations xiii

Rethinking the Corporation: Introduction

Renate E. Meyer, Stephan Leixnering and Jeroen Veldman

Concentrated Ownership, Socioemotional Wealth, and the "Third Possibility": Bringing Society Back In

Loizos Heracleous and Luh Luh Lan

The Elusive Nature of Shareholders' Claims over

the Corporation, Or the Strange Non-Death of Shareholder Primacy

Olivier Butzbach

Constitutionalizing the Corporation

Anna Grandori

Exploring the Middle Way: The Istituto per la Ricostruzione Industriale (IRI) in Between Corporate Capitalism and Planned Economy (1948-1973)

Patrizio Monfardini, Paolo Quattrone and Pasquale Ruggiero

The Past as Prologue: Purpose Dynamics in the History of the Aktiengesellschaft

Stephan Leixnering, Renate E. Meyer and Peter Doralt

Community, Enterprise, and Self-Help: The Coevolution of Capitalism and Non-Profit and For-Profit Businesses in Britain and Germany

Heather A. Haveman and Nataliya Nedzhvetskaya

Shareholder Value or Public Purpose? From John Maynard Keynes and Adolf Berle to the Modern Debate Suzanne J. Konzelmann, Victoria Chick and Marc Fovargue-Davies 
Social Ontology of the Modern Corporation: Its Role in Understanding Organizations

Jeroen Veldman and Hugh Willmott

Rethinking the Purpose of the Corporation with the Creative Power of the Enterprise

Blanche Segrestin, Armand Hatchuel and Kevin Levillain

Learning from Alternatives: Analyzing Alternative Ways of Organizing as Starting Points for Improving the Corporation Joost Luyckx, Anselm Schneider and Arno Kourula

Concluding Reflections: The Future of the Corporation and Research on the Corporate Form

Gerald F. Davis 


\section{ABOUT THE CONTRIBUTORS}

Olivier Butzbach is a Senior Researcher in Political Economy at the Department of Political Science of the University of Campania "Luigi Vanvitelli" (Italy). His main research interests are in the fields of comparative capitalism, institutional and organization theory. His latest book is a volume co-authored with Kurt von Mettenheim for Routledge, Financialization of the Economy in the United States.

Victoria Chick is an Emeritus Professor of Economics at University College London. She has written articles and books on money, Keynes's economics and methodology, including her book on Keynes's General Theory, Macroeconomics After Keynes. She was a Founding Member of the Post-Keynesian Economics Society and is a Life Member of that and of the Association for Heterodox Economics. She is an Advisor to Rethinking Economics. She has held visiting posts in Europe and North America and the Reserve Bank of Australia.

Gerald F. Davis is the Ruth and Gilbert Whitaker Professor of Management and Professor of Sociology at the University of Michigan's Ross School of Business. His research is on how the digital transformation of business is unfolding in different institutional terroirs around the world. His latest book is Taming Corporate Power in the $21^{\text {st }}$ Century.

Peter Doralt is a Professor Emeritus of Commercial and Company Law at WU Vienna University of Economics and Business. From 1975 until his retirement in 2007, he held a Chair at WU and was the First Head of WU's Institute (later Department) of Business Law. For decades, he has been a Consultant to the Austrian Federal Ministry of Justice in issues of business law. In addition, he has been active as a Supervisory Board Member of business firms for more than 30 years.

Marc Fovargue-Davies is a Research Associate of the Cambridge University Centre for Business Research.

Anna Grandori is a Professor of Business Organization at Bocconi University and currently Editor-in-Chief of European Management Review. Through a strongly interdisciplinary approach to organization she analyzed decision-making, organization design, interfirm networks, entrepreneurship and firm governance. Recent works have particularly focused on renewing the theory of the firm and democratizing firm governance. 
Armand Hatchuel is a Professor of Management Science at MINES ParisTech, PSL University. He pioneered research on the cognitive dynamics of collective action and on creative design. He has co-authored several awarded books and papers, and his work together with Blanche Segrestin has inspired the new French corporate law. He is a Member of the French Academy of Technologies.

Heather A. Haveman is a Professor of Sociology and Business at the University of California, Berkeley. She studies how organizations, industries, and employees' careers evolve, and the impact of organizations on their employees and society. Her work combines insights from institutionalism, organizational demography, social movements, political economy, and social history.

Loizos Heracleous is a Professor of Strategy at Warwick Business School and Associate Fellow at Oxford University. He earned his PhD from the Judge Business School, University of Cambridge. His research focuses on organization change, corporate governance, and organizational discourse and has been published in 10 books and over 80 papers in leading journals.

Suzanne J. Konzelmann is a Professor in Economics at Birkbeck, University of London, where she directs Birkbeck's Postgraduate Programmes in Corporate Governance and Business Ethics. She is also the Co-Executive Editor of the Cambridge Journal of Economics, a Research Associate of the Cambridge University Centre for Business Research, and a Council Member of the Progressive Economy Forum.

Arno Kourula is an Associate Professor at the University of Amsterdam Business School, The Netherlands. His research emphasis is on corporate sustainability through cross-sector interactions. He has published several articles in leading journals in management, business ethics, political science, and environmental studies. He serves as a Section Editor at the Journal of Business Ethics.

Luh Luh Lan is an Associate Professor of Law with the Business School and Law School of the National University of Singapore (NUS). She received her LLM from Cambridge University Law School and her PhD in Business Policy from NUS. Her research interests are in corporate law and corporate governance and she publishes in both management and law journals. She is currently a research member of ECGI and a board member of GCGC and ICGS, respectively.

Stephan Leixnering is a Senior Scientist at the Research Institute for Urban Management and Governance, WU Vienna University of Economics and Business. His research focuses on issues of organizational governance in the public and the private sector, the emergence of organizational forms, and ethical aspects of organization and management. He holds research affiliations with MINES ParisTech and Zeppelin University and was a Visiting Scholar at Stanford University. 
Kevin Levillain is an Assistant Professor of Management at MINES ParisTech, PSL University. His research focuses on new corporate governance frameworks for social responsibility and innovation. He received several awards for the books he wrote and co-edited with Blanche Segrestin and Armand Hatchuel, which inspired the introduction of Sociétés à mission in French corporate law.

Joost Luyckx is a Postdoctoral Research Fellow of Research Foundation Flanders (FWO) at the Research Centre for Work \& Organisation Studies of KU Leuven. His research interests include corporate (il)legitimacy and power, alternative organizing, and the politicization of climate change by social movements. He has published in journals such as Organization Studies and Organization.

Renate E. Meyer is the Chair of Organization Studies at the WU Vienna University of Economics and Business. She is also a Part-time Professor in Institutional Theory at Copenhagen Business School. She holds visiting positions at the University of Oxford and the University of Alberta. Her research focuses on processes of institutionalization and translation, institutional renewal, multimodality, collective action in crises, as well as governance structures and governance gaps mostly in urban contexts. She is the Editor-in-Chief of Organization Studies and the Past Chair of the Academy of Management's OMT Division.

Patrizio Monfardini is an Associate Professor of Business Administration at the University of Cagliari (Italy). His research deals with performance measurement and management systems in the public sector.

Nataliya Nedzhvetskaya is a graduate student in the Department of Sociology at the University of California, Berkeley. Her research examines the origins and diffusion of index funds in the US financial industry. Her interests include economic sociology, organizations and labor.

Paolo Quattrone is a Professor of Accounting, Governance, and Society at the Alliance Manchester Business School, where he is also the Director of the Centre for the Analysis of Investment Risk. His research deals with the organizing effects of calculative practices. He is the incoming Co-Editor-in-Chief of Organization Studies.

Pasquale Ruggiero is an Associate Professor of Business Administration and Public Management at the University of Siena (Italy) and a Senior Lecturer in Public Financial Management at the Brighton Business School (UK). His research deals with public sector organizations and their management accounting and management control systems.

Anselm Schneider is a Senior Lecturer in Organization Theory at Stockholm Business School, Stockholm University. He is interested in the role of business in sustainable development and different forms of business regulation. His research has been published in journals such as Organization Studies and the Journal of Management Studies. 
Blanche Segrestin is a Professor in Management Sciences at MINES ParisTech, PSL University, where she holds the chair "Theory of the Enterprise." Her research focuses on the modern enterprise, its creative power, and its implications for corporate governance and corporate law. The book Refonder l'entreprise (2012, with A. Hatchuel) inspired the French legal form of purpose-drivencorporations.

Dr. Jeroen Veldman is Associate Professor at Nyenrode Business University; Honorary Senior Visiting Fellow at Bayes Business School, and Corporate Governance Section Editor at Journal of Business Ethics. He has published in Human Relations, British Journal of Management, Cambridge Journal of Economics, and Critical Perspectives on Accounting. He received the 2019 AOM International Impactful Collaboration Award.

Hugh Willmott (PhD Manchester University; Honorary PhD, Lund University) is a Professor of Management at Cass Business School and a Research Professor in Organization Studies, Cardiff Business School. He previously held professorial appointments at UMIST (now Manchester Business School) and the Judge Business School, Cambridge. He is a Fellow of the British Academy. He is a past Associate Editor of Academy of Management Review and Associate Editor of Organization. He has also served on the editorial boards of Accounting, Organizations and Society, Journal of Management Studies and Organization Studies. His research interests hinge around the application of critical social theories to the study of management and organizations. 


\section{FOREWORD: RESEARCH IN THE SOCIOLOGY OF ORGANIZATIONS}

Research in the Sociology of Organizations (RSO) publishes cutting edge empirical research and theoretical papers that seek to enhance our understanding of organizations and organizing as pervasive and fundamental aspects of society and economy. We seek provocative papers that push the frontiers of current conversations, that help to revive old ones, or that incubate and develop new perspectives. Given its successes in this regard, RSO has become an impactful and indispensable fount of knowledge for scholars interested in organizational phenomena and theories. RSO is indexed and ranks highly in Scopus/SCImago as well as in the Academic Journal Guide published by the Chartered Association of Business schools.

As one of the most vibrant areas in the social sciences, the sociology of organizations engages a plurality of empirical and theoretical approaches to enhance our understanding of the varied imperatives and challenges that these organizations and their organizers face. Of course, there is a diversity of formal and informal organizations - from for-profit entities to non-profits, state and public agencies, social enterprises, communal forms of organizing, nongovernmental associations, trade associations, publicly traded, family owned and managed, private firms - the list goes on! Organizations, moreover, can vary dramatically in size from small entrepreneurial ventures to large multinational conglomerates to international governing bodies such as the United Nations.

Empirical topics addressed by Research in the Sociology of Organizations include: the formation, survival, and growth or organizations; collaboration and competition between organizations; the accumulation and management of resources and legitimacy; and how organizations or organizing efforts cope with a multitude of internal and external challenges and pressures. Particular interest is growing in the complexities of contemporary organizations as they cope with changing social expectations and as they seek to address societal problems related to corporate social responsibility, inequality, corruption and wrongdoing, and the challenge of new technologies. As a result, levels of analysis reach from the individual, to the organization, industry, community and field, and even the nation-state or world society. Much research is multi-level and embraces both qualitative and quantitative forms of data.

Diverse theory is employed or constructed to enhance our understanding of these topics. While anchored in the discipline of sociology and the field of management, Research in the Sociology of Organizations also welcomes theoretical engagement that draws on other disciplinary conversations - such as those in political science or economics, as well as work from diverse philosophical traditions. RSO scholarship has helped push forward a plethora theoretical 
conversations on institutions and institutional change, networks, practice, culture, power, inequality, social movements, categories, routines, organization design and change, configurational dynamics and many other topics.

Each volume of Research in the Sociology of Organizations tends to be thematically focused on a particular empirical phenomenon (e.g., creative industries, multinational corporations, entrepreneurship) or theoretical conversation (e.g., institutional logics, actors and agency, microfoundations). The series publishes papers by junior as well as leading international scholars, and embraces diversity on all dimensions. If you are scholar interested in organizations or organizing, I hope you find Research in the Sociology of Organizations to be an invaluable resource as you develop your work.

Professor Michael Lounsbury

Series Editor, Research in the Sociology of Organizations Canada Research Chair in Entrepreneurship \& Innovation University of Alberta 